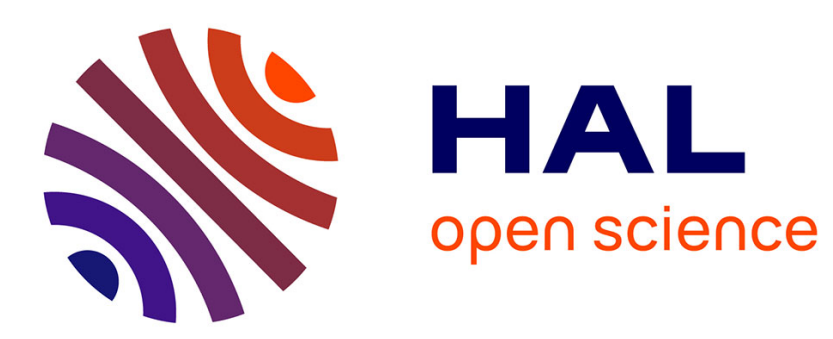

\title{
Making the subsurface political: How enhanced oil recovery techniques reshaped the energy transition
}

\author{
Sébastien Chailleux
}

\section{To cite this version:}

Sébastien Chailleux. Making the subsurface political: How enhanced oil recovery techniques reshaped the energy transition. Environment and Planning C: Politics and Space, 2019, $10.1177 / 2399654419884077$. hal-02306835

\section{HAL Id: hal-02306835 \\ https://hal.science/hal-02306835}

Submitted on 7 Oct 2019

HAL is a multi-disciplinary open access archive for the deposit and dissemination of scientific research documents, whether they are published or not. The documents may come from teaching and research institutions in France or abroad, or from public or private research centers.
L'archive ouverte pluridisciplinaire HAL, est destinée au dépôt et à la diffusion de documents scientifiques de niveau recherche, publiés ou non, émanant des établissements d'enseignement et de recherche français ou étrangers, des laboratoires publics ou privés. 
Making the subsurface political: How enhanced oil recovery techniques reshaped the energy transition

Abstract: Analyzing the case of France, this article aims to explain how the development of enhanced oil recovery (EOR) techniques over the last decade contributed to politicizing the subsurface - that is, putting underground resources at the center of social unrest and political debates. France faced a decline of its oil and gas activity in the 1990s, followed by a renewal with subsurface activity in the late 2000s using EOR techniques. An industrial demonstrator for carbon capture and storage was developed between 2010 and 2013, while projects targeting unconventional oil and gas were pushed forward between 2008 and 2011 before eventually being canceled. We analyze how the credibility, legitimacy and governance of those techniques were developed and how conflicts made the role of the subsurface for energy transition the target of political choices. The level of political and industrial support and social protest played a key role in building project legitimacy, while the types of narratives and their credibility determined the distinct trajectories of hydraulic fracturing (HF) and carbon capture and storage (CCS) in France. The conflicts over EOR techniques are also explained through the critical assessment of the governance framework that tends to exclude civil society stakeholders. We suggest that these conflicts illustrated a new type of politicization of the subsurface by merging geostrategic concerns with social claims about governance, ecological demands about pollution and linking local preoccupations to global climate change.

Keywords: Carbon capture and storage; hydraulic fracturing; energy transition; politicization; France

Analyzing the case of France, the article explains how the development of enhanced oil recovery (EOR) techniques over the last decade contributed to politicizing the subsurface. Politicization deals with conflicts and involves phenomena such as mobilizations, public debates, political action or a decision. In contrast, neutralization processes such as the technicization of an issue (Kenis and Lievens 2017) or the naturalization of a mechanism (Swyngedouw in Sheppard and McMaster 2004) must be considered as depoliticization tactics because they eliminate the possibility of choice. Following the debates over the role of multi-level policies (Cowell et al. 2017) and the role of policy entrepreneurs (Mintrom and Luetjens 2017), this article questions the politicization of technical choices for the energy transition, how investments are made and the role of national/subnational levels in defining the meaning of such technical solutions. Taking the opposite view of ecological modernization, this article asserts that social mobilization remains central in defining the meaning of a technology. Drawing on the politics of scale (Huber and Emel, 2009; Bloomfield and Doolin, 2017), we investigate how scalar conflicts are key in explaining conflicting views about the role of the subsurface for energy transition and the dynamics between technical solutions and conflicting national/subnational frameworks. 
Two EOR techniques - hydraulic fracturing and carbon dioxide injection - have been a part of redefining energy transition scenarios in France in the past two decades. Unconventional oil and gas extracted with hydraulic fracturing increase the fossil fuel inventory and empower narratives about the golden age of gas as a desirable energy transition (Boersma and Jordaan 2017). Geological carbon storage makes it possible to control downstream flows of carbon, reduce the carbon footprint and envision less radical energy transition scenarios (Praetorius and Schumacher 2009). However, both techniques have been heavily criticized, although with different narratives and differing impacts. Studying the case of France, this article explains how social movements, political debates and industrial involvement framed the role of those techniques. While local and national public and collective actions prevented the development of shale gas through a ban on fracking (Chailleux, Merlin, and Gunzburger 2018), carbon storage was mostly constrained by a weak European carbon market (Scott et al. 2012). Therefore, comparing the trajectories of these two techniques offers insight about the processes framing their meaning at different scales. We analyze how the credibility, legitimacy and governance were debated and how those debates made the role of subsurface for energy transition the target of political choices.

The article is based on two separate research projects. The first was on unconventional oil and gas in France (2008-2014) conducted using 29 semi-directive interviews and discourse analysis of a corpus of 338 French press articles and seven official reports. Main arguments and actors were identified in the articles and we analyzed their variation over time. We also analyze the role of the different editorial policies and journalists' specializations, but this exceeded the scope of this article (see Matthews and Hansen 2018). We did not analyze the narratives in social media (see Stasik 2018). Official reports provided insights about the legitimized type of knowledge and actors in the policy arena. The second project was on carbon capture and storage (CCS) controversies (1997-2017) showing narrative evolution from a corpus of 579 French press articles, state-of-the-art storage projects and 11 interviews. Interviews were used to reconstruct actors' discourses and understand the means they used to publicize their claims. Official reports and existing policies provided indications about the legitimate framing of the technology.

This article starts with a state of the art on the politicization of the subsurface and the presentation of variables. The two main sections address the cases of hydraulic fracturing and CCS to highlight the different trajectories both EOR techniques followed. Finally, we discuss the limitations of considering technical solutions for energy transition as apolitical means instead of furthering their credibility, legitimacy and governance.

\section{The politicization of the subsurface for the energy transition}

Extractive industries long determined land uses and channeled investment toward primary commodities that favored capital accumulation through dispossession (Moore 2017, 2018) and restructured social orders (Le Billon and Sommerville 2017). Underground resources are not like other commodities because they are 
mostly state-owned and used in international bargaining and governed by national policies. Many extractive countries derive power from the extraction of national underground resources, contributing to building authoritative rentier states (Mitchell 2013; Ross 2013). The development of the subsurface is thus the common outcome of both public and private investments in land, technologies, infrastructures and markets (Le Billon and Sommerville 2017; Bridge and Le Billon 2017). Oil has been the major determinant of such political orders because it has also shaped societies (Bonneuil and Fressoz 2013; Bridge and Le Billon 2017) and politics of scales (Huber and McCarthy 2017) adapted to the consumption and production of fossil fuels. However, Europe, and especially France, had their own extractive industries - mostly mines that were delocalized from the 1970s - and the subsurface stopped being a national political topic outside trade for resources. Climate change brought new attention to the subsurface issue for European countries through the promotion of a decarbonized energy transition. While the climate issue was reframed as a problem of carbon emissions (Aykut and Dahan 2015), negative emission schemes and geoengineering supported carbon geological storage to delink economic expansion from emissions (Anshelm and Hansson 2016). Industrial development of renewables also generated new needs for subsurface resources (Calvert 2016; Huber and McCarthy 2017). The energy transition has renewed interest in the subsurface from two different angles: it calls for new subsurface uses (gas and hydrogen storage, nuclear waste and $\mathrm{CO}_{2}$ storage, geothermal energy production) and emphasizes previous extractive activities such as mining and fossil fuel production driven by increasing demand, rent-seeking and technological innovation. Controlling the subsurface is thus mainly about political power, but new projects involving the subsurface are now more conflictual and require a reassessment of the political structure governing underground resources. We will focus on three gaps in the literature we want to address.

First, a common bias of the literature on global change is to study the role of the subsurface from a global point of view, which fails to fully grasp the local conditions where the actors' rationality is tested and where global trends meet local translation. Global considerations about the role of the subsurface define the political aspect of underground resources through a geostrategic lens and the discussion is about how energy production is handled in international relations (Mitchell 2013, Le Billon and Kristoffersen 2019) or in national politics with regard to economic interests (Huber and Emel 2009). This sort of politicization only deals with a top-down process where dominant players have organized worldwide extraction at the cost of local populations with virtually no agency. This focus is often critical but it silences the local and national creation of meaning and legitimacy.

Second, another stream in the literature does the opposite, stressing the local translation of mining, oil and gas activities and emphasizing a socioecological politicization process. This process is related to the compromises on the social production of space (Huber and McCarthy 2017) and it is clearly visible in works on sacrificed areas (Shade 2015). It differs from the former process because it takes a bottom-up approach and questions the representations and the knowledge usually mobilized to make sense of the subsurface 
(Richardson and Weszkalnys 2014; Kinchy, Parks, and Jalbert 2016). However, such research is often onesided in favor of the opponents' representations and narratives (Widener 2018; Bebbington and Bury 2013), with a few exceptions (Bowker 1987; Braun 2000).

Third, even though the revolution of unconventional oil and gas expanded the scope of extractive industries (Evensen 2018; Neville et al. 2017), comparisons between mining, oil and gas projects concerned mainly extractive countries (Bebbington and Bury 2013). Europe in general and France in particular are not included (Gunzburger et al. 2017; Chailleux 2019). Moreover, such comparisons focused on extractive industries and failed to consistently analyze the subsurface uses including the difficult question of geological storage (Lidskog and Sundqvist 2004).

Our argument is that the contestation of a new use of the subsurface (CCS) or against the introduction of new techniques (HF) broke down the apolitical definition of the projects. The politicization we studied in France is threefold. First, the subsurface was made political through social mobilization that not only criticized the local impacts of the project but also the larger consequences for climate change, energy transition policies and governance. This opened an opportunity for political choice despite the initial apolitical definition of the projects. Second, the subsurface was made political through political action and policymaking that not only governed the critics (Topçu 2013) but also intended to address these transscalar issues. The subsurface was forced into the political arena and stressed the need to shape a legal framework adapted to the stakes of energy transition. Third, those debates initiated new representations of a vertical environment (Clark 2013; Elden 2013) - meaning that the relationships between the subsurface, the surface and the atmosphere were used to contest the legitimacy of geostrategic mining precedence. We suggest a growing awareness of the local population on the risks, the legitimate uses and the type of governance tools that should be implemented about the projects related to the subsurface.

Previous politicization on nuclear storage (Barthe 2006) participated in the movement, but the cases of CCS and shale gas differ because of the potential number of sites concerned (a few hundred wells in the case of shale gas versus one site for nuclear waste), the legal framework (nuclear governance is separate from mining regulations), and political divisions (French officials are skeptical about hydraulic fracturing, neutral about CCS but in support of nuclear energy). Therefore, we assert that the introduction of EOR techniques in France enables new actors to politicize not only the degradation linked to a specific project but also the subsurface by questioning its role in the energy transition. The demonstration is based on three main variables: credibility, legitimacy and governance of the projects using EOR techniques.

Credibility refers to the demonstration of feasibility and risk assessment, which are social constructions determined by political context and social demand (Cash et al. 2002; Radaelli 2005; Hilgartner 2000). The variable measures the level of certainty of three types knowledge used to make sense of a technology and/or a project. First, technical and scientific credibility looks at the nature and status of the knowledge 
promoters use to impose their projects. Second, economic credibility refers to the market acceptability of the project and its business model; it is measured through price signals and forecasted profitability. Third, project credibility is assessed in the scenario for the future it suggests. We evaluate how a project promotes its role in ecological crises in general, and in the energy transition more specifically.

Legitimacy assesses how three main types of actors consent to a project through the way they speak about it and coalesce either to defend or contest it. Consent is a coproduction of credible knowledge, social representations, legal procedures and wealth redistribution (Jasanoff 2004; Schmidt 2013). We look at the industrial, political and social actors at different scales to measure their support and the narratives they broadcast. Social actors target mostly opponents and the scale at which they are mobilized. Political actors encompass mainly members of parliament and the central government and we look at the type of public support, decisions and policies adopted. Industrial actors gather the companies involved in the project and we look at the scale of projects; level of investment; and demonstration pilot, exploration or exploitation. Legitimacy is derived from the level of conflict between those actors: a low level of conflict means high legitimacy, while a high level of conflict means low legitimacy.

Governance refers to the structured relationships between coalitions of actors enshrined in existing regulations at different institutional levels (Hooghe and Marks 2002; Brenner 2004). We look at how the legal framework regulates activity but also at the participatory procedures implemented to see who is involved in the decision-making (Schmidt 2013). We also question the funding schemes and investment practices supporting those projects and how they relate to democratic public choices (Labussière and Nadaï 2018). The governance tools help generate legitimacy because they support or obstruct the ability to compromise.

\section{Hydraulic fracturing: An innovation enabling the expansion of fossil fuel resources}

The industrial and inter-governmental global narratives about hydraulic fracturing (HF-EOR) failed to meet legitimacy and credibility in France because of high social mobilization, weak political and industrial support and inadequate regulation.

\subsection{Industrial and inter-governmental global narratives about a new deal for energy}

HF-EOR developed mainly in the United States in the late 1990s to access shale gas and oil in increasing the permeability of the shale by cracking the rocks with water, sand and chemicals. Although shale gas was not discovered in the 1990s, it only became profitable with the dramatic increase in the price of gas in the 2000s, but also because of deregulation, mineral rights, political support (Andrews and McCarthy 2014), economies of scale and existing infrastructures such as pipelines (Wang and Krupnick 2015). HF-EOR increases the costs of drilling by about $60 \%$, thus reducing the profitability. Its business model therefore relies on high fossil fuel prices and political support for energy independence. In the 2000s, the United 
States was experiencing both. The shale boom (Rabe and Borick 2013) relied on policy incentives supported by the Bush Administration exempting the industry of environmental obligations. Power production shifted from coal to gas during the last decade contributing to decrease American carbon emission.

International agencies promoted the development of gas through the use of HF-EOR to compensate for the oil decline. The agency supported the discourse about the end of cheap oil, a message that was also found in the American Hirsch Report in 2005 (Bridge and Wood 2010). Gas was then one of the most favorable energy transition options, with the IEA arguing for a "golden age of gas" (IEA, 2010) and "golden rules for a golden age of gas" (IEA, 2011), promoting the American transition from coal to gas. The development of shale gas provided a convenient response to the global price increase of raw materials. For the IEA, unconventional gas doubles global gas resources (IEA, 2011). Therefore, the new profitability of unconventional resources opens the door to new assessments of energy futures.

Hydraulic fracturing makes the "expansion of extractivism" (Svampa, 2016) possible. In fact, contrary to conventional hydrocarbon, unconventional gas can be found in many areas of the globe. In 2011, the Energy Information Agency (EIA) from the U.S. Department of Energy published an assessment of the shale oil and gas resources in 14 different countries that could potentially change the geography of energy for the next century (EIA, 2011). Such types of assessment are based on comparison with American geology analogues and are mostly conjecture, but they produced a rush toward the verification of potential resources. These new resources changed energy orientations in many countries, redirecting investments toward gas rather than renewables. In Europe, Poland and France were targeted as the most promising areas for shale gas. Hydraulic fracturing thus enables a reassessment of the geostrategic interests especially in fossil-fuels dependent countries such as France.

Global narratives about HF-EOR promoted the development of unconventional oil and gas. This endeavor relied on technical knowledge, global forecasts, political support and increasing commodities prices. However, the success of HF-EOR is an American success that is not replicable elsewhere.

\subsection{National translation through expert narratives}

Once shale gas development reached France in 2010, it was transposed into an existing legal framework and administrative practices that were not created to sustain either the scale of development nor territorial opposition.

The development of unconventional oil and gas in France was marginal, which limited both supporters' expectations and political support. By the end of the 1990s and in the early 2000s, oil majors sold their licenses to smaller companies because the remaining conventional resources were deemed unprofitable. Only three exploration licenses for shale gas were granted in 2010 in southeastern France and a dozen licenses targeted shale oil in the Paris basin in 2008, reflecting a modest endeavor even with another 64 
licenses under assessment. Furthermore, as oil majors withdrew from exploration and exploitation activities, the Union Française des Industries Pétrolières (UFIP) professional association became dominated by oil refining and distribution companies. When junior exploration companies arrived in the 2000s, they were outsiders to this professional association, which did not support their claims and interests. Few of them had the resources or will to communicate with local stakeholders during exploration.

The French regulatory structure tends to exclude local actors and the administrative department managing the licenses is marginal within the administration, lessening political attention. Oil and gas licenses are granted by the Bureau Exploration Production Hydrocarbures (BEPH), a department of the Ministry of Ecology. The BEPH had a particularly marginal role in the Ministry because its declining activities did not interest its hierarchy, ministries or members of parliament (MPs) (Chailleux, Merlin, and Gunzburger 2018). This disinterest grounded to a halt adapting the regulation of the subsurface, the Code minier, which was relatively favorable to oil and gas companies. According to French subsurface mineral rights, a mine has no private owner and the State grants exploration and exploitation licenses based on technical and financial abilities of the company making a claim. Exploration licenses encompass neither local consultation, nor authorization from landowners (only exploitation licenses required public inquiry at that time). The BEPH therefore granted licenses within the confinement of the administrative process. Furthermore, the tax regime principally favors the central state depending on the amount of resources extracted, so landowners and local elected have little incentive to accept extractive industries. Furthermore, hydraulic fracturing was unregulated.

The dedicated vocabulary of the industry enshrined in the legal framework overshadowed the ability of experts and policymakers to anticipate the controversial aspects of shale gas and hydraulic fracturing. All the interviews conducted with professionals have shown how the very definition of what "unconventional" means fluctuates through time. Professionals explained hydraulic fracturing is also used to stimulate conventional oil exploitation and that horizontal drilling could be used without hydraulic fracturing. Both techniques are deemed to have been mastered by oil companies for decades. Therefore, neither the government nor the companies foresaw the potential conflicts associated with hydraulic fracturing, a longmastered technique. Press analysis shows that most of the few articles published before December 2010 were quite positive toward hydraulic fracturing (Fig. 1). This technology was seen through the prism of the American shale boom, which brought with it increased tax revenues, profits and energy independence.

Blindness to potential conflicts concerning hydraulic fracturing was enabled by the existing regulations and sustained by political disinterest. The weak and disorganized industry was unable to generate political support or upstream social legitimacy.

\subsection{Local opposition and risk definition}


In late 2010, a flash mobilization (Terral 2012) succeeded in ascribing a new public meaning to hydraulic fracturing as a threat to the environment and public health and in gaining the support of most French officials for this definition. Mobilization grew locally from established activists and political networks. Mobilization started in southeastern France in December 2010 (nine months after licenses were granted). José Bové, known for his opposition to GMOs and with a deep connection to the Larzac plateau (a historic landmark for the French altermondialiste [alternative globalization] movement and for resistance to state infrastructures in the 1970s), organized a public meeting that set off a national movement (Chailleux 2015). Simultaneously, regional officials from the left and green parties began mobilizing their own networks to make shale gas a public problem. The first activists stressed that hydraulic fracturing posed an environmental threat based on the situation in the United States described in the movie Gasland (Fox, 2010). They linked the recent licenses granted for their land to this threat and others such as landscape degradation, competition for water resources, opaque procedures, a lack of consultation and risks for local economies (Fig. 1). Those licenses generated a state of emergency in bringing foreign threats (Gasland) into local lands (Larzac), and opponents claimed for the State to act upon this threat. Critics of the technique relied on alternative assessments of its impact that shook its credibility. For example, opponents referenced the work of one local academic hydrogeologist from Montpellier who claimed that the specificities of the underground in southeastern France, made of faults and cavities, could not safely support the drilling of gas wells (Université de Montpellier 2, 2011).

The flash mobilization percolated to the Paris basin in February 2011. The common claim was about cancelling the licenses and rejecting the use of hydraulic fracturing. The Paris basin did not raise the same concerns about landscapes because it is mainly an area of productive agriculture that was already used for small-scale conventional oil exploitation. Here, hydraulic fracturing was defined as a threat for underground water because the areas in question provide fresh water to the 10 million inhabitants of the Paris metropolitan area. Moreover, the area covered by the licenses was located in the districts of majority leaders of parliament, a year before the general election of 2012. The "anti" discourse then became more general. It was not only about these localized projects, but rejected all kinds of hydrocarbon projects as opponents adopted the motto of "shale gas, not here, not anywhere". They criticized the contradiction between developing shale gas and promoting energy transition in a country where power is produced with nuclear energy and not coal. 


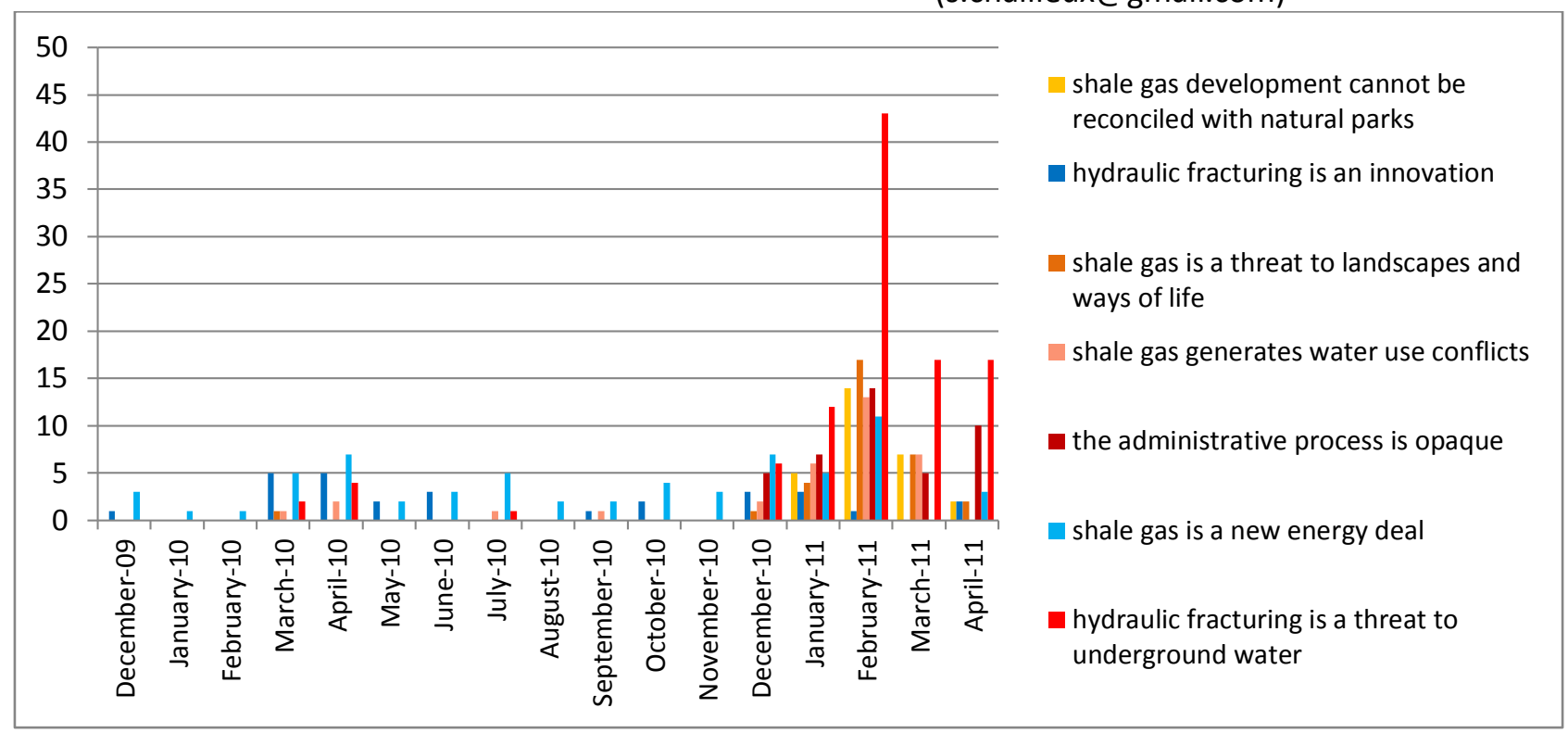

Figure 1. Narratives on shale gas in the media (2009-2011).

Companies were disorganized and disagreed about the value of unconventional oil and gas. Lundin wanted nothing to do with such projects. Vermilion Energy, which had both conventional exploitation and unconventional exploration projects, soon withdrew their unconventional projects from the table to shield their conventional wells from protests. Total had only obtained a license in France to master hydraulic fracturing associated with horizontal drilling, so the potential economic impact was not very significant for the company (in fact, the company then moved to Denmark to test hydraulic fracturing). Only two junior companies had strong interests in such unconventional projects: Schuepbach Energy for shale gas and Toreador for shale oil. They were both eager to validate potential resources to sell back their licenses to major companies but they did not engage with the publics at that time.

There was also no audible political support for shale gas during this period and MPs sided with opponents. The French Minister of Ecology took the lead on the issue. She was newly nominated and distanced herself from the former minister who signed the licenses. After the failure of an administrative committee to review the granting of those licenses in February, the majority leader, from the Paris basin, introduced a bill to ban unconventional oil and gas in late March. To settle the controversy, the parliament forbade the use of hydraulic fracturing because it was the only legal option to cancel the licenses without facing lawsuits from companies. The Jacob Act (Loi 2011-835) forbids hydraulic fracturing but allows experimentation and has a provision for an annual revision of the ban based on technological progress, leaving the door open for alternative techniques. In July 2011, the dominant public opinion was that hydraulic fracturing was an uncertain and threatening technique, but the status of unconventional resources remained unresolved.

After the ban, most of the companies abandoned the development of unconventional resources, but some political actors tried to resuscitate the industry by experimenting with alternative techniques and exploring unconventional resources to secure energy independence and fund energy transition (Weile 2014). They 
Pre print 09/2019 for Environment and Planning C

Chailleux Sébastien, E2S UPPA, Passages

(s.chailleux@gmail.com)

faced the opposition of a social movement that was against all types of stimulation of the subsurface. Opponents stressed the contribution of shale gas to carbon emission but they mostly denounced the signal sent to the population of developing fossil fuels instead of renewables. The granting of licenses dramatically decreased after 2011 even for conventional resources. The controversy ended in 2017 with a bill prohibiting all types of oil stimulation and the end of exploitation by 2040.

Despite global narratives about an energy new deal, the national framing on HF-EOR kept its development in check. Weak industrial support generated neither political support nor social legitimacy. Despite an existing regulation favoring its development, this case shows the capacity of local movements to curtail global industry and to efficiently advocate for limitations on what the Earth can sustain underground (water pollution, seismicity), on the ground (landscape, water consumption) and in the air (methane leaks, GHG emissions).

\section{Carbon capture and storage: The constraints of controlling energy consumption residue}

The development of carbon capture and storage (CCS-EOR) came about from another EOR technique but the technology aims to reduce greenhouse gas (GHG) emissions from power production and steel and cement plants and thus participates to climate change solutions.

\subsection{An engineering dream}

Developed in the 1970s, CCS is part of geoengineering techniques to perpetuate the development model of continuous economic growth (Hayden 2014) in storing the $\mathrm{CO}^{2}$ emitted by industrial activities in geological formation. The first CCS promoters were scientists who advocated for its development and were supported by European research programs since 1993. The goal was to demonstrate the feasibility of this technological promise (O'Neill and Nadaï 2012). According to the French geological survey (Bureau de Recherche Géologique et Minière - BRGM):

It was about studying the concept's feasibility because some people were questioning the role of mankind on climate. Even if we were not sure about it, there was pressure from the Commission to have at least a research project to see what the possibilities could be. In fact, in this project, we studied the possibilities of capturing $\mathrm{CO}_{2}$ from industrial facilities, to transport it by pipeline, and then store it in the ground.

The first major industrial demonstrator project in Europe was located offshore in the North Sea in Norway, and it targeted $\mathrm{CO}_{2}$ emitted for oil production from 1996.

France did not have a strong interest in national implementation of CCS projects because its energy mix was already quite decarbonized. French political support aims the creation of a national expertise to be exported worldwide, similar to what was done for nuclear energy. In 2002, the "Club $\mathrm{CO}_{2}$ " was $\mathrm{created}$ in 
France, bringing together the BRGM, the French Institute of Petroleum (Institut Français du Pétrole) and the French agency for industrial risk management (INERIS). They aimed to combine their expertise to promote CCS technology. During the 2000s, the main issue was technological and confined to experts' debates: exploring for storage sites, monitoring potential leakage and seismicity, and developing capture technology (and lowering the costs of those techniques). In Europe, those actors promoted CCS as a climate mitigation tool and a new business opportunity (through the carbon market). The linking of this engineering dream to the climate agenda was central to its development and funding. The 2005 IPCC report brought credibility to CCS in the struggle over climate change.

Actors including power producers, oil and gas companies, chemical industries and research centers created the Zero Emission Platform (ZEP) in 2005 to promote CCS in the EU. Coal-power plants were the main target of the technology to reduce carbon emissions in power production. Oil producers were the chief operator of the industrial consortiums because they had the necessary subsurface expertise. However, the question of funding these costly projects remained a salient issue. O'Neill and Nadai (2012) noticed the ZEP lobbied to include CCS in the NER300 energy transition program, funding CCS demonstrators across Europe through the provision of 300 million Euros in quotas for the European Union Emission Trading Scheme (EU ETS), and to pass a directive on CCS in 2008, committing EU member states to implementing national CCS projects. The European Energy Program for Recovery also provided nearly one billion euro for the same purpose. This opportunity considerably increased attention on CCS demonstrators and new projects emerged. Total demonstrated the full cycle of oxy-combustion technology in a depleted gas field near Lacq, France, between 2009 and 2013. Investing 100 million Euros, Total showed its good will to act upon climate change. Industrial projects were also developed in the Netherlands in 2010 and in Germany. Shackley and Evar (in Markusson, Shackley and Evar, 2012) confirmed this rise in public attention toward CCS in 2010. The Conference of the Parties (COP) had been lobbied since 2005 to include CCS in clean development mechanisms and expectations were high for the COP15 to adopt a clear position. However, no consensus was reached before the COP17 in Durban in 2011. The window of opportunity then closed because CCS credibility, governance and legitimacy were challenged.

\subsection{Social and market acceptability}

Social acceptability is the first obstacle mentioned by CCS supporters when you asked them why CCS projects failed to develop. In fact, every onshore project in Europe faced a certain amount of local opposition. However, ideological critics from global ENGOs, especially Greenpeace in 2008, did not meet their goal except when they mobilized locally to oppose actual projects (O'Neill and Nadai, 2012). The Dutch Barendrecht project failed because of local opposition claiming property devaluation along with Greenpeace efforts denouncing a short-term climate solution (Brunsting et al. 2011; Margriet Kuijper 2011). In Germany, three projects were abandoned because of local opposition, leading the government in 
2014 to devolve implementation of the EU directive on CCS to the federal states (länders). In France, the opposition in Lacq was relatively minor and did not stop the project. However, opponents raised questions about the safety of the technique, potential leaks, seismicity, and impacts on surface activities such as growing and selling wine. The historical presence of Total in the vicinity also allowed for closer communication with local officials. However, the social acceptability of CCS suffered from the same governance framework regarding the subsurface. France transposed the EU directive in 2010 through an update to the mining code but the French regulations continued to mostly exclude local actors. When participative tools were implemented, they were well monitored and goal oriented. The committee Total put in place Total was composed of a majority of project supporters while ENGOs held a minority of seats. The committee focused on technical aspects and the community was not allowed to offer any input. The lack of debate did not set the record on CCS and other projects could face more structured opposition in areas without previous links with promoters. Promoters failed to address opposition to CCS as one part of a global opposition against carbon-intensive ways of life that is visible in movements against hydrocarbons such as 350.org or Desinvest (Ayling and Gunningham 2017).

The take-off of CCS did not occur as planned in Europe mostly for economic reasons. Following the drop in EU ETS, the NER300 program failed to fund any CCS projects for two main reasons: too many quotas were granted to industrial companies, which overestimated their growth before the 2007 financial crisis; and the 2007 financial crisis slowed both economic growth and GHG emissions, making it less relevant to implement CCS and contributing to devaluate the EU ETS. The IEA notes that USD\$30bn in funding was announced between 2007 and 2010, but less than USD\$3bn was actually spent (IEA, 2016: 39). The negative economic narrative won out over the narrative about CCS being a strategic investment in 2012 and remained strong afterward (Fig. 2), reflecting the cycle of hype and disillusionment showed in the UK (Nerlich and Jaspal 2013). Another reason for this economic despair was the unexpected growth of renewables during the same period. In Europe, renewables grew quicker and more cheaply than expected by coal energy facilities and oil and gas producers. CCS then became more marginal in the struggle against GHG emissions in the energy sector. Power companies backed away from the supporting platforms.

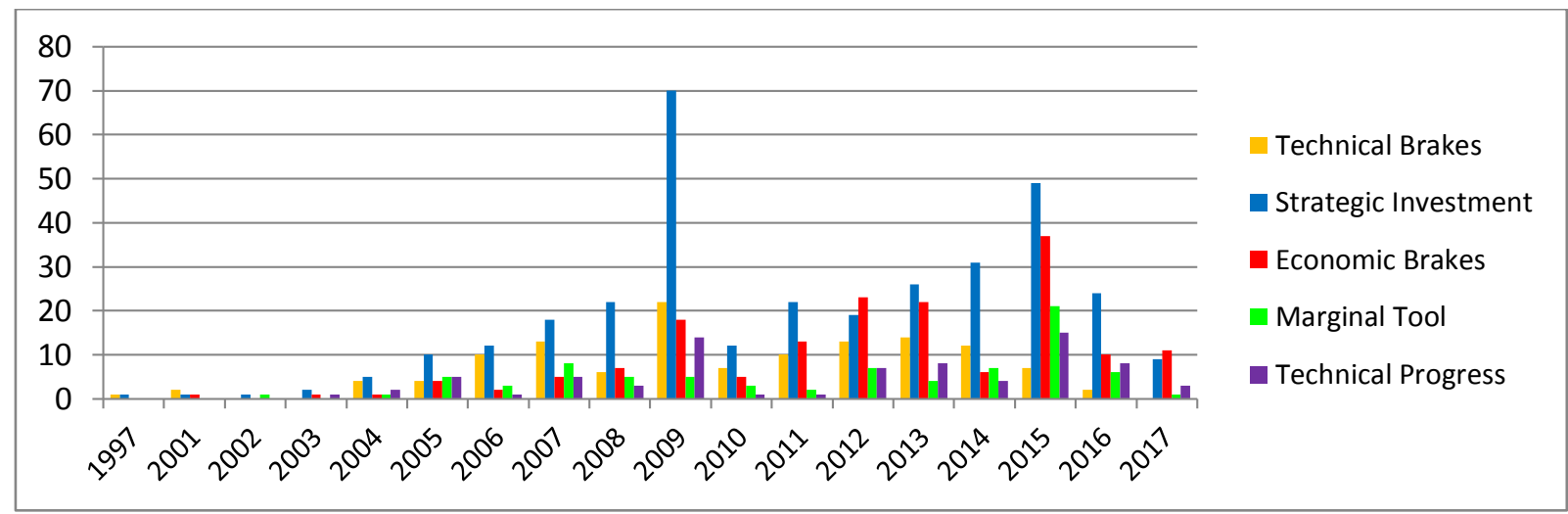

Figure 2. Main narratives about CCS in the French press (584 articles). 


\subsection{Resistance to critics and building irreversibility}

Contrary to hydraulic fracturing, CCS stays in the European and French political portfolio because the solution adapted to the critics. A new European-level funding scheme is now emerging for 2020 and climate policy roadmaps all include CCS to tackle non-power related emissions. Nevertheless, the renewal has remained hypothetical because CCS is not high on the political agenda and few industrial actors show an interest in it. However, the endeavor led by Total associated with Norwegian Equinor (ex-Statoil) and Dutch Shell should be noted for the new CCS promotion model. To respond to critics about social acceptability and economic profitability, CCS promoters in Europe transformed their narratives following the COP21 in Paris. First, a new network of actors took the lead on CCS. Power producers left and refineries, cement and steel factories became the main target because their activities emit $\mathrm{CO}_{2}$. Oil and gas companies stay the main promoters through the Oil and Gas Climate Initiative (OGCI). Second, to facilitate the social license to operate, new projects are offshore carbon storage, thereby avoiding governance issues. Onshore storage is thought to be more conflictual, and new Norwegian, Dutch and English projects target the North Sea, which is becoming the European carbon storage facility. This follows the third transformation, which is the emergence of a new business model splitting the CCS chain between storage and capture. This is based on the Norwegian model of Gassnova, the public manager of CCS-related funding and projects. The idea is that it is too complicated for a single company to manage capture, transportation and storage, so an emitter would only have to manage capture, which is part of its expertise. Transportation and storage are left to an external service provider, which would be an oil producer because it has the effective subsurface expertise. Fourth, an alternative model led by scientists is promoted through diversified and smaller projects. Smaller projects emerged (IEA, 2016: 26), at times combined with geothermal production, other times combined with biomethane production to obtain negative emissions. Those scientists are looking for new allies in the geothermal production rather than with oil and gas companies and they convinced French policymakers to push forward their model in the 2018 Carbon Neutral policy.

This new CCS model relies on the justification that CCS remains an efficient tool to meet the target of +2 degree Celsius above pre-industrial levels by 2050. This justification was disseminated through scenarios for the future and roadmaps. Most of the scenarios that include CCS have been produced by the International Energy Agency (IEA), the Global CCS Institute or other national platforms promoting CCS. CCS was deemed to be an efficient tool but its share varied in the different scenarios and has decreased since the mid-2000s because of the late development of the projects. For example, the IEA 2006 report put the figure between $20 \%$ and $28 \%$ while its 2016 report had a target of $12 \%$, which is more closely aligned with the Paris Agreement, which calls for $14 \%$. These scenarios frame the future (Metze 2018) and attempt to build what Chateauraynaud and Debaz (2017) called irreversibility. They claim that CCS is necessary to achieve the political goal of carbon emission reduction by 2050, along with the roadmap to achieve this goal. Promoters, such as the French Institute of Petroleum (IFPEN), defend this stance: 
What is certain is that in the future, if we want to be carbon neutral, without CCS, I do not know how to do it. So, we either commit to neutrality, or we let it go. But if we want carbon neutrality, natural carbon sinks are insufficient. So without CCS, I do not know how we can do it. Or, we have cut on energy consumption and in that case, we enter into hard stuff.

CCS received political support despite meager media and public attention because the promoters successfully coined the solution as the only one susceptible to tackle climate change while also maintaining the status quo of the fossil fuel-based development model. As the interview shows, contesting CCS means opening a political debate about the whole model of development.

However, these scenarios are controversial and the politicization seems to be incomplete in France because the debates have only concerned the local scale and did not questioned the role of CCS in zero carbon transition. First, the share of CCS does not match the technology's actual development. Comparing projections from the 2000s to more recent estimates, CCS development is now expected to be increasingly rapid. The EU planned to have 12 large-scale demonstrators by 2012 in 2008; none have yet been built. The IEA 2010 roadmap set out plans for 100 projects by 2020. In 2018, the CCS institute made a list of 17 largescale facilities operating worldwide; only four were dedicated to saline aquifer storage while the others were dedicated to EOR (IEA, 2016). Second, looking at the geographical distribution of the CCS investment effort to be sustained worldwide, $75 \%$ of the countries included in the IEA projections were outside the OECD, especially in China. However, actual geological data describes an uncertain future for CCS opportunities in China and India. They do not possess adequate and identified storage sites and the cost for exploration far exceeds investment. The slow pace of development reflects the overoptimistic assumptions of CCS supporters (Hansson and Bryngelsson 2009). CCS must overcome significant hurdles before the technological promise can materialize. CCS has not yet reached a turning point, but its advocates have warned that another lock-in is on the horizon: it will be too late to achieve the $+2^{\circ} \mathrm{C}$ scenario. Finally, in the French case, CCS plays its part in the long term Carbon Neutral policy but no debate was engage on the cost and relevance of such technical solution. While the policy officer in charge of CCS in the Ministry of Ecology laments about the lack of public debate, new funding is granted to research projects to map smaller geological reservoirs and test new techniques.

\section{Debating about EOR techniques makes the subsurface political and defines energy transition}

Table 1. Synthesis of the main variables defining the use of EOR techniques in France.

\begin{tabular}{|c|c|c|c|}
\hline \multicolumn{2}{|l|}{ Variables } & \multicolumn{2}{|c|}{ Politicization of EOR techniques in France } \\
\hline & & $\mathrm{HF}$ & CCS \\
\hline \multirow{2}{*}{ Credibility } & Technical knowledge & Uncertain and abandoned & Uncertain but developing \\
\hline & Economic model & Favorable & Unfavorable \\
\hline
\end{tabular}




\begin{tabular}{|c|c|c|c|c|}
\hline & Scenario fol & he future & Golden age of gas & Limiting GHG emissions \\
\hline & & $\begin{array}{ll}\text { For local } & \\
\text { residents } & \end{array}$ & $\begin{array}{l}\text { Strong opposition on the } \\
\text { technique and the } \\
\text { governance }\end{array}$ & $\begin{array}{l}\text { Moderate opposition on } \\
\text { the technique and the } \\
\text { governance }\end{array}$ \\
\hline & $\begin{array}{c}\text { Social } \\
\text { support } \\
\text { and frame }\end{array}$ & $\begin{array}{l}\text { For national } \\
\text { actors }\end{array}$ & $\begin{array}{l}\text { Strong opposition on the } \\
\text { technique and the } \\
\text { governance }\end{array}$ & $\begin{array}{l}\text { Low opposition on the } \\
\text { marginal role }\end{array}$ \\
\hline Legitimacy & & $\begin{array}{l}\text { Related to the } \\
\text { ecological crisis }\end{array}$ & $\begin{array}{l}\text { Strong opposition on } \\
\text { environmental threat and } \\
\text { energy transition }\end{array}$ & $\begin{array}{l}\text { Moderate critics on the } \\
\text { marginal role }\end{array}$ \\
\hline & Political sup & ort and frame & Opposition on the technique & $\begin{array}{l}\text { Weak but steady support } \\
\text { based on the marginal role }\end{array}$ \\
\hline & Industrial si & port and frame & $\begin{array}{l}\text { Marginal support based on } \\
\text { exploration and } \\
\text { experimentation }\end{array}$ & $\begin{array}{l}\text { Major support based on } \\
\text { demonstration }\end{array}$ \\
\hline Governance & Existing reg & ation & Absent (landing) - ban & $\begin{array}{l}\text { Absent (landing) - } \\
\text { favorable }\end{array}$ \\
\hline & Participatio & & Exclusive of local actors & Inclusive of local actors \\
\hline
\end{tabular}

The comparison between the trajectory of hydraulic fracturing and CCS in France shows the struggles on the credibility, legitimacy and governance of these technical solutions. Through those struggles, both the subsurface and the techniques used to act upon it are politicized because actors debated about the meaning of using the subsurface for energy transition, calling for political action, social mobilization or industrial investment. This politicization is new in France because it involves a political choice which had previously been confined through technical and administrative processes. The debates reopened major political questions such as who should decide, how conflicting knowledge should be assessed and how long-term transitory projects should be governed in conjunction with short-term political terms. We underline how the politicization of the subsurface in France addressed those issues to underscore the originality of the process in a country marked by a decline in its extractive industries. The subsurface was made political following a traditional process of mobilization leading to a political response, but it also led to changes in the representations about the surface for the mobilized stakeholders: opponents developed awareness about the vertical relationships between the subsurface, the surface and the atmosphere. Therefore, the introduction of EOR techniques made the political choices behind the technofixes visible. This has three main implications regarding energy transition policymaking. 
First, technical solutions for energy transition are limited by triple credibility tests encompassing technical and scientific certainty, the economic context and their role in climate scenarios. Although credibility in our case studies did not appear to be a sufficient condition for the success of a technical solution alone, it remains a necessary condition. EOR techniques in particular called into question the climate scenario and how the Earth's limits are determined. EOR techniques participate in imposing energy lock-in and futurity framing (Metze 2018); in other words, the definition of the anticipated impacts of an activity at different timescales and the urgency to act. EOR techniques also reopened the debate between physical and social limits of the Earth (Bridge and Wood 2010; Huber 2009) in epitomizing the power of technological progress to expand resource frontier boundaries (Svampa, 2016). New social limits changed the ways decisionmakers anticipated the necessary action to tackle climate change. As a result, while natural resource scarcity is a growing political issue (Bazilian 2018), EOR techniques contributed to blurring forecasting ability and thus being able to anticipate adequate political action, preserving the status quo, falling back to Hotelling's curse (1931), which describes strong incentives toward the exhaustion of non-renewable resources in the absence of political intervention. Politicization of hydraulic fracturing in France brought that issue to light and led to political action to phase out fossil fuels while the absence of such debate in the case of CCS left the problem unresolved.

Second, legitimacy of EOR techniques is created through conflicts at different scales involving different categories of actors. Successful actors framed the project in relation to the local area, national policies and the global ecological crisis. Hydraulic fracturing was restrained in France because it lacked political and industrial support and faced a high level of social mobilization. CCS did not face such a black-and-white outcome and the door remained open to many more future possibilities. Against the central-local spectrum of governance, Total played its local card with the Lacq demonstrator and was able to more easily integrate the local ecosystem compared to the troubling waters of the EU financing scheme. The company can be considered as an important policy entrepreneur supporting a particular view of climate change (Mintrom and Luetjens, 2017). Therefore, not only are national governance mechanisms important in shaping the legitimacy of such technical solutions, but local politics and industrial investment seem to play a more decisive role in producing a network of allies defending the same project. The question of legitimacy in our comparison puts the conflict between actors at the center of the issue, as well as how they each defined the projects, their techniques and the desirable transition they wanted for their land. While the subsurface is ascribed new purposes for the global energy transition (Huber and McCarthy 2017), opponents also described it as a part of their local environment (water resources, seismic activity, pollution, etc.). Controversies resulted from a collision of different scales of discourse and action and they reorganized the social framework (Chateauraynaud and Debaz 2017). They politicized what was previously excluded from debate. Politicization thus appears necessary to reorganize the relationships between actors and scales to favor a legitimate energy transition. 
Third, governance mechanisms played a central role in the early stage of definition of those technical solutions. In both cases, the existing regulation favored industrial access to the resource and failed to include the local population. The lack of transparency fueled a major social movement, especially in the hydraulic fracturing case. Regulation determines the procedures that will produce both credibility and legitimacy. In favoring industrial actors over the local population, regulation fueled the opportunity for conflicts. Downstream impact assessment and unregulated innovation show a lack of planning and in the end weaken both the credibility and legitimacy of the technical solutions. Moreover, existing regulation questions the investment processes in energy transition and how public and private funding is allocated in climate policies. While market instrumentation of the transition has been criticized for its uneven outcomes (Labussière and Nadaï 2018), we showed with the CCS case how the cost of CCS demonstrators and the carbon market structure they rely on were political choices that were not fully debated. This lack of democratic debates about the allocation process of R\&D funding (Carolan 2006) calls into question the ability of the EU in general and France in particular to move forward with a "just transition" (Newell and Mulvaney 2013). Investing in CCS is a way for oil and gas companies - as well as for experts of the subsurface - to anticipate post-oil carbon business while maintaining their expertise and infrastructures. The investment in shale gas or in carbon sequestration rerouted billions toward halfway solutions without any public participation. This kind of top-down governance seems distant from the interdependencies between national and devolved governments that work on demonstrated local energy transition policies (Cowell et al. 2017). Governance frameworks facilitate or preclude compromises, and in the case of France, it encouraged conflict rather than debate.

\section{Conclusion}

Comparing the development of hydraulic fracturing and CCS in France, we showed that both referred to a specific vision of the world that put the burden of liberating humankind from the limits of growth on technological progress. However, this article focused on the conflicts over those technical fixes because they were open to criticism that included credibility, legitimacy and governance issues. EOR techniques participated in politicizing the subsurface in France by shedding light on its role in the local environment as well as for the national energy transition and the global struggle against climate change. The subsurface became a new object of broad political interest in linking geostrategic concerns, knowledge production and legitimization, and socioecological claims which integrated various scales of conflict. This politicization of the subsurface is now likely to expand as more uses of the underground are developed in France, including geothermal power production, gas and hydrogen storage and new mining activities.

\section{$\underline{\text { References: }}$}


Andrews, Eleanor, and James McCarthy. 2014. "Scale, Shale, and the State: Political Ecologies and Legal Geographies of Shale Gas Development in Pennsylvania." Journal of Environmental Studies and Sciences 4 (1): 7-16.

Aykut, Stefan C, and Amy Dahan. 2015. Gouverner le climat?: 20 ans de négociations internationales. Paris: Presses de Sciences Po.

Ayling, Julie, and Neil Gunningham. 2017. "Non-State Governance and Climate Policy: The Fossil Fuel Divestment Movement." Climate Policy 17 (2): 131-49.

Barthe, Yannick. 2006. Le Pouvoir d'indécision - La Mise En Politique Des Déchets Nucléaires. Economica. Paris.

Bazilian, Morgan D. 2018. "The Mineral Foundation of the Energy Transition." The Extractive Industries and Society 5 (1): 93-97.

Bebbington, Anthony, and Jeffrey Bury. 2013. Subterranean Struggles: New Dynamics of Mining, Oil, and Gas in Latin America. Austin: University of Texas Press.

Boersma, Tim, and Sarah M. Jordaan. 2017. "Whatever Happened to the Golden Age of Natural Gas?” Energy Transitions 1 (2).

Bonneuil, Christophe, and Jean-Baptiste Fressoz. 2013. L'événement anthropocène: la Terre, I'histoire et nous. Paris: Éd. du Seuil.

Bowker, Geof. 1987. “Pictures from the Subsoil, 1939.” The Sociological Review 35 (1_suppl): 221-54.

Braun, Bruce. 2000. "Producing Vertical Territory: Geology and Governmentality in Late Victorian Canada." Ecumene 7 (1): 7-46.

Brenner, Neil. 2004. New State Spaces: Urban Governance and the Rescaling of Statehood. Oxford New York: Oxford University Press.

Bridge, Gavin, and Philippe Le Billon. 2017. Oil. 2nd ed. Resources. Cambridge, UK ; Malden, MA: Polity Press.

Bridge, Gavin, and Andrew Wood. 2010. "Less Is More: Spectres of Scarcity and the Politics of Resource Access in the Upstream Oil Sector." Geoforum 41 (4): 565-76.

Brunsting, Suzanne, Marjolein de Best-Waldhober, C.F.J. (Ynke) Feenstra, and Tom Mikunda. 2011. "Stakeholder Participation Practices and Onshore CCS: Lessons from the Dutch CCS Case Barendrecht." Energy Procedia 4: 6376-83.

Calvert, Kirby. 2016. “From 'Energy Geography' to ‘Energy Geographies': Perspectives on a Fertile Academic Borderland." Progress in Human Geography 40 (1): 105-25.

Carolan, Michael S. 2006. "Science, Expertise, and the Democratization of the Decision-Making Process." Society \& Natural Resources 19 (7): 661-68.

Cash, David, William C. Clark, Frank Alcock, Nancy M. Dickson, Noelle Eckley, and Jill Jäger. 2002. "Salience, Credibility, Legitimacy and Boundaries: Linking Research, Assessment and Decision Making." SSRN Scholarly Paper ID 372280. Rochester, NY: Social Science Research Network. 
Chailleux, Sébastien. 2015. Non Au Gaz de Schiste ! : Cadrages et Débordements de La Controverse Sur Les Hydrocarbures Non Conventionnels En France et Au Québec. Thèse pour l'obtention du doctorat en science politique, Université de Bordeaux.

- - - 2019. "Strategic Ignorance and Politics of Time: How Expert Knowledge Framed Shale Gas Policies." Critical Policy Studies, January, 1-19.

Chailleux, Sébastien, Julien Merlin, and Yann Gunzburger. 2018. "Unconventional Oil and Gas in France: From Popular Distrust to Politicization of the Underground." The Extractive Industries and Society 5 (4): 682-90.

Chateauraynaud, Francis, and Josquin Debaz. 2017. Aux bords de l'irréversible: sociologie pragmatique des transformations. Petra. Paris.

Clark, Nigel. 2013. "Geoengineering and Geologic Politics." Environment and Planning A: Economy and Space 45 (12): 2825-32.

Cowell, Richard, Geraint Ellis, Fionnguala Sherry-Brennan, Peter A Strachan, and David Toke. 2017. "SubNational Government and Pathways to Sustainable Energy." Environment and Planning C: Politics and Space 35 (7): 1139-55.

Elden, Stuart. 2013. "Secure the Volume: Vertical Geopolitics and the Depth of Power." Political Geography 34 (May): 35-51.

Energy Information Agency (2011) World Shale Gas Resources: An Initial Assessment of 14 Regions Outside the United States, US Department of Energy

Energy Information Agency (2016) International energy outlook, US Department of Energy.

Evensen, Darrick. 2018. "Yet More 'Fracking' Social Science: An Overview of Unconventional Hydrocarbon Development Globally." The Extractive Industries and Society 5 (4): 417-21.

Gunzburger, Yann, Marie-France Agnoletti, Michel Deshaies, Samuel Ferey, and Pascal Raggi. 2017. "Social Perception of Unconventional Gas Extraction on the Outskirts of a Former Coal-Mining Area in Northeast France." The Extractive Industries and Society 4 (1): 53-62.

Hayden, Anders. 2014. When Green Growth Is Not Enough: Climate Change, Ecological Modernization, and Sufficiency. Montreal ; Kingston ; London ; Ithaca: McGill-Queen's University Press.

Hilgartner, Stephen. 2000. Science on Stage: Expert Advice as Public Drama. Writing Science. Stanford, Calif: Stanford University Press.

Hooghe, Liesbet, and Gary Marks. 2002. Multi-Level Governance and European Integration. Rowman and Littlefield.

Hotelling H. (1931) "The Economics of Exhaustible Resources", Journal of Political Economy, 39: 137-175

Huber, Matthew T. 2009. "Energizing Historical Materialism: Fossil Fuels, Space and the Capitalist Mode of Production." Geoforum 40 (1): 105-15.

Huber, Matthew T, and James McCarthy. 2017. "Beyond the Subterranean Energy Regime? Fuel, Land Use and the Production of Space." Transactions of the Institute of British Geographers 42 (4): 655-68. 
International Energy Agency (2011) The golden age of gas, IEA

International Energy Agency (2012) World Energy Outlook, IEA

International Energy Agency (2016) 20 years of Carbon Capture and Storage - Accelerating future deployment, IEA.

International Panel on Climate Change - Metz B et al. (2005) Special report on Carbon Capture and Storage, UNEP.

Jasanoff, Sheila. 2004. States of Knowledge: The Co-Production of Science and the Social Order. $1 \mathrm{New}$ edition. London: Routledge.

Kenis, Anneleen, and Matthias Lievens. 2017. "Imagining the Carbon Neutral City: The (Post)Politics of Time and Space." Environment and Planning A: Economy and Space 49 (8): 1762-78.

Kinchy, Abby, Sarah Parks, and Kirk Jalbert. 2016. "Fractured Knowledge: Mapping the Gaps in Public and Private Water Monitoring Efforts in Areas Affected by Shale Gas Development." Environment and Planning C: Government and Policy 34 (5): 879-99.

Le Billon, Philippe, and Berit Kristoffersen. 2019. "Just Cuts for Fossil Fuels? Supply-Side Carbon Constraints and Energy Transition." Environment and Planning A: Economy and Space, January, 0308518X1881670.

Le Billon, Philippe, and Melanie Sommerville. 2017. "Landing Capital and Assembling 'Investable Land' in the Extractive and Agricultural Sectors." Geoforum 82 (June): 212-24.

Lidskog, Rolf, and Göran Sundqvist. 2004. "On the Right Track? Technology, Geology and Society in Swedish Nuclear Waste Management." Journal of Risk Research 7 (2): 251-68.

Margriet Kuijper, Ir. 2011. "Public Acceptance Challenges for Onshore CO2 Storage in Barendrecht." Energy Procedia 4: 6226-33.

Matthews, Julian, and Anders Hansen. 2018. "Fracturing Debate? A Review of Research on Media Coverage of 'Fracking.'” Frontiers in Communication 3 (September).

Metze, Tamara. 2018. "Framing the Future of Fracking: Discursive Lock-in or Energy Degrowth in the Netherlands?" Journal of Cleaner Production 197 (October): 1737-45.

Mintrom, Michael, and Joannah Luetjens. 2017. "Policy Entrepreneurs and Problem Framing: The Case of Climate Change." Environment and Planning C: Politics and Space 35 (8): 1362-77.

Mitchell, Timothy. 2013. Carbon Democracy: Political Power in the Age of Oil. London: Verso.

Moore, Jason W. 2017. "The Capitalocene, Part I: On the Nature and Origins of Our Ecological Crisis." The Journal of Peasant Studies 44 (3): 594-630.

---. 2018. "The Capitalocene Part II: Accumulation by Appropriation and the Centrality of Unpaid Work/Energy." The Journal of Peasant Studies 45 (2): 237-79.

Neville, Kate J., Jennifer Baka, Shanti Gamper-Rabindran, Karen Bakker, Stefan Andreasson, Avner Vengosh, Alvin Lin, Jewellord Nem Singh, and Erika Weinthal. 2017. "Debating Unconventional Energy: Social, Political, and Economic Implications." Annual Review of Environment and Resources 42 (1): 241-66. 
O’Neill, Rebecca, and Alain Nadaï. 2012. "Risque et Démonstration, La Politique de Capture et de Stockage Du Dioxyde de Carbone (CCS) Dans I'Union Europeenne." Vertigo 12 (1).

Praetorius, Barbara, and Katja Schumacher. 2009. “Greenhouse Gas Mitigation in a Carbon Constrained World: The Role of Carbon Capture and Storage." Energy Policy 37 (12): 5081-93.

Rabe, Barry G., and Christopher Borick. 2013. "Conventional Politics for Unconventional Drilling? Lessons from Pennsylvania's Early Move into Fracking Policy Development: Conventional Politics for Unconventional Drilling." Review of Policy Research 30 (3): 321-40.

Radaelli, Claudio M. 2005. “Diffusion without Convergence: How Political Context Shapes the Adoption of Regulatory Impact Assessment." Journal of European Public Policy 12 (5): 924-43.

Richardson, Tanya, and Gisa Weszkalnys. 2014. "Introduction: Resource Materialities." Anthropological Quarterly 87 (1): 5-30.

Ross, Michael. 2013. The Oil Curse: How Petroleum Wealth Shapes the Development of Nations. Princeton University Press.

Schmidt, Vivien A. 2013. "Democracy and Legitimacy in the European Union Revisited: Input, Output and 'Throughput.'” Political Studies 61 (1): 2-22.

Scott, Vivian, Stuart Gilfillan, Nils Markusson, Hannah Chalmers, and R. Stuart Haszeldine. 2012. "Last Chance for Carbon Capture and Storage." Nature Climate Change 3 (December): 105.

Seranne M et al. (2011) Le gaz de schiste dans le Sud de la France, Université de Montpellier 2.

Shade, Lindsay. 2015. "Sustainable Development or Sacrifice Zone? Politics below the Surface in PostNeoliberal Ecuador." The Extractive Industries and Society 2 (4): 775-84.

Sheppard, Eric S., and Robert Brainerd McMaster, eds. 2004. Scale and Geographic Inquiry: Nature, Society, and Method. Malden, MA: Blackwell Pub.

Stasik, Agata. 2018. "Global Controversies in Local Settings: Anti-Fracking Activism in the Era of Web 2.0." Journal of Risk Research 21 (12): 1562-78. https://doi.org/10.1080/13669877.2017.1313759.

Swyngedouw, Erik. 2010. “Apocalypse Forever?” Theory, Culture \& Society 27 (2-3): 213-32.

Terral, Pierre-Marie. 2012. "La fronde contre le gaz de schiste : essai d’histoire immédiate d'une mobilisation éclair (2010-2011)." Ecologie \& politique 45 (2): 185.

Topçu, Sezin. 2013. La France Nucléaire. L'art de Gouverner Une Technologie Contestée. Le Seuil.

Wang, Zhongmin, and Alan Krupnick. 2015. "A Retrospective Review of Shale Gas Development in the United States." Economics of Energy \& Environmental Policy 4 (1): 5-18.

Weile, Rene. 2014. "Beyond the Fracking Ban in France." Journal of European Management and Public Affairs Studies 1 (2).

Widener, Patricia. 2018. "National Discovery and Citizen Experts in Aotearoa New Zealand: Local and Global Narratives of Hydraulic Fracturing." The Extractive Industries and Society 5 (4): 515-23. 
Anshelm, Jonas, and Anders Hansson. 2016. "Has the Grand Idea of Geoengineering as Plan B Run out of Steam?" The Anthropocene Review 3 (1): 64-74.

Hansson, Anders, and Mårten Bryngelsson. 2009. “Expert Opinions on Carbon Dioxide Capture and Storage-A Framing of Uncertainties and Possibilities." Energy Policy 37 (6): 2273-82.

Labussière, Olivier, and Alain Nadaï, eds. 2018. Energy Transitions: A Socio-Technical Inquiry. 1st edition 2018. Energy, Climate and the Environment. Cham, Switzerland: Palgrave Macmillan.

Nerlich, Brigitte, and Rusi Jaspal. 2013. "UK Media Representations of Carbon Capture and Storage: Actors, Frames and Metaphors." Metaphor and the Social World 3 (1): 35-53.

Newell, Peter, and Dustin Mulvaney. 2013. “The Political Economy of the 'Just Transition': The Political Economy of the 'Just Transition.'” The Geographical Journal 179 (2): 132-40. 